\title{
Vitamin D nutrition of healthy schoolchildren from North India
}

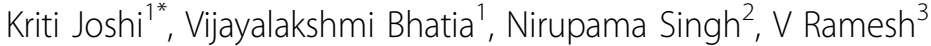 \\ From 8th APPES Biennial Scientific Meeting \\ Darwin, Australia. 29 October - 1 November 2014
}

Vitamin D deficiency is not expected in prepubertal schoolgoing children in a sunny country like India since they should have good sunshine exposure in conjunction with school activities. However data from India in this age group are scant.

\section{Aims}

To evaluate the vitamin D status of apparently healthy prepubertal vs pubertal schoolchildren and to examine the influence of gender and socioeconomic status on serum 25 hydroxyvitamin D (25OHD).

\section{Methods}

Children referred to the pediatric endocrinology clinic for growth evaluation, interpretation of thyroid functions, concern regarding delayed puberty, etc and found to be normal were enrolled, as were their healthy siblings. Pubertal assessment, a food frequency questionnaire for calcium, sunlight exposures (minutes of sunshine exposure from $10 \mathrm{AM}-4 \mathrm{PM}$ ) and percentage of skin exposed were recorded. Serum calcium, albumin, creatinine, alkaline phosphatase (ALP), 25OHD and iPTH were assayed.

\section{Results}

118 children (69\% prepubertal ) were enrolled. Vitamin D deficiency $(25 \mathrm{OHD}<20 \mathrm{ng} / \mathrm{ml})$ was present in $71.6 \%$ of prepubertal and $87.8 \%$ of pubertal children. Mean 25 OHD was significantly higher in the prepubertal as compared to the pubertal group $(16.0 \pm 7.9$ versus $10.6 \pm 7.5$ $\mathrm{ng} / \mathrm{ml}, \mathrm{p}=0.001)$. Their calcium intake and sunlight exposure was also significantly higher. Girls had lower mean $25 \mathrm{OHD}$ as compared with boys $(12.9 \pm 7.6$ vs $16.0 \pm 8.4, \mathrm{p}=0.02)$, lower calcium intake $(569 \pm 270 \mathrm{vs}$
$712 \pm 334 \mathrm{mg}, \mathrm{p}=0.02)$ and less sunlight exposure (46.7 \pm 45.8 vs $75.1 \pm 39.1$ minutes, $\mathrm{p}=0.001)$ than their male counterparts. There was no significant difference in 25OHD of upper, middle and lower socioeconomic classes. We found a significant correlation between serum 25OHD and calcium intake $(r: 0.238, p=0.02)$, duration of sunlight exposure $(\mathrm{r}: 0.235, \mathrm{p}=0.02)$ and body surface area exposed ( $\mathrm{r}: 0.28, \mathrm{p}=0.003$ ). There was a significant negative correlation between 25OHD and PTH levels $(\mathrm{r}:-0.45, \mathrm{p}<0.001)$

\section{Conclusions}

Pubertal children have lower 25OHD than prepubertal children, probably due to limitation of outdoor activities on the background of high demand. There is significant gender bias against girls for both calcium intake and sun exposure, resulting in lower serum 25OHD than in boys.

\section{Authors' details}

'Department of Endocrinology, Sanjay Gandhi Post Graduate Institute of Medical Sciences, Lucknow, India. ${ }^{2}$ Department of Dietetics, SGPGIMS, Lucknow, India. ${ }^{3}$ Department of Pathology, SGPGIMS, Lucknow, India.

Published: 28 April 2015

doi:10.1186/1687-9856-2015-S1-P65

Cite this article as: Joshi et al: Vitamin D nutrition of healthy schoolchildren from North India. International Journal of Pediatric Endocrinology 2015 2015(Suppl 1):P65. 